\title{
COLLOQUIA
}

KATALIN ESZTER MORGAN

Germany

Forum Pedagogiczne

2018/1

Wpłynęło: 03.09.2017

Zatwierdzono do druku: 31.03 .2018

DOI: $10.21697 / \mathrm{fp} .2018 .1 .18$

\section{HOW DO TRAUMATIC SHOAH-WITNESS TESTIMONIES FIT INTO GERMAN HISTORY EDUCATION?}

\begin{abstract}
This essay traces ways in which traumatic Shoah witness testimonies fit into German history curricula conceptually by highlighting the competencies with which pupils are meant to grasp the topic of National Socialism and the Holocaust. Such curricula are diverse and they keep the learning objectives and teaching methods pertaining to emotions, imagination and ethical dimensions - as relevant to the topic - abstractly vague. This poses certain challenges and opportunities for history teachers and pupils. One such opportunity is the incorporation of virtual video-graphed Shoah witness testimonies that by their nature are emotional as they narrate traumatic memories. The opportunity in such narrations lies in assigning the function of tertiary witnessing to pupils and this process is briefly described. The challenges of using such oral histories can be understood as those that clash with the non-discursively organised knowledge in pursuit of truth (verifiable facts) by means of what is traditionally considered historical evidence.
\end{abstract}

Key words: Holocaust Education, emotions, trauma, history curriculum, Geschichtsdidaktik, competencies, dualism.

\section{Introduction: Holocaust Education scholarship and history curricula in Germany}

In this essay I explore how the testimonies of Shoah survivors recorded on an educational DVD software fit into German history curricula. I proceed by firstly outlining the underlying principles of such curricula conceptually and comparatively. Thereafter, I discuss the role of emotions in German Geschichtsdidaktik, which is the study and application of appropriate methods and scientific principles underlying the teaching and learning of history as a discipline. Finally, I touch on some theoretical concepts that are relevant for understanding what happens when pupils watch and listen to traumatic testimonies and thus become tertiary witnesses to such narratives. 
Holocaust Education scholarship in Germany is distinct. Unlike in other countries where young people may be horrified and even paralysed to learn about what happened as a result of Nazi Germany throughout Europe (if they do in fact learn about the Holocaust ${ }^{1}$ ), in Germany this learning experience is coupled to the fact that what happened is part of family history (Crossland 2012). Using witness testimonies to learn about the Holocaust not only opens up the possibility of powerful emotional experiences for the recipients. It is also tied to a moral or moralising dimension, because in the German context, school curricula, in addition to factual historical knowledge impartation, also want to sensitise pupils to the extraordinary responsibility that the government must accept as the successor state of the Third Reich (Meseth \& Proske 2010, p. 202).

Hence it is not just a matter of being emotionally touched when listening to survivor testimonies that, by their very nature, are rather emotional. It is also not just a generalised aim "to overcome prejudice, intolerance, and hatred - and the suffering they cause - through the educational use of [video testimonies]", as is the mission statement of the University of Southern California's Shoah Foundation whose materials are used for the presented study. It is also about guilt, responsibility and a constant search for absolution or Entlastungsprozesse (Lücke 2009, p. 5) or Entlastungsbedürfnisse (Kühner 2008, p. 64) related to the actual historical event itself, and not a cognate social justice issue as is the case in many other countries. Entlastung literally refers to processes of or a desire for un-burdening oneself either from guilt, or from responsibility, or both (see Brauer \& Wein 2010). There is a word often used in association with learning about the Holocaust. It is "emotionalising" an historical content for didactic purposes. It actually means "moralising" and it shows that the connection between emotions and history learning has a moralistic undertone. "Emotionalising" is not about the doubtlessly emotional content of testimonies or their possible transferral onto the recipient. Rather, it is about (the perception of) being manipulated in some way, usually to be (or perceived to be) made feel guilty about the perpetrator past. Thus emotions in German Holocaust education discourse tend to be associated first and foremost with feelings of guilt rather than other types of feelings, like those that the victims might have experienced, for example.

Much has been written about Germany's exemplary confrontation with its past, but similarly, much has also been said about the silencing of this history at the family level. Therefore, while in official and political accounts we might find plenty of examples of how Germany has dealt with its past and paid for its crimes, at the level of personal remembrance and memory there are gaps and silences. To some extent schools have a mandate to speak into this silence, but not in a straight forward or prescriptive way. In general history education, the competencies pupils are meant to develop focus on mental operations of imagining and understanding,

1 In some Swiss provinces, for example, it is not mandatory to learn about the Holocaust at schools.

2 https://sfi.usc.edu/about, last accessed 30 January 2018. 
whereby a distinction is made between Sachurteil, (factual or "subject matter competence", Körber 2011, p. 151) which is establishing relationships between sets of information, and Werturteil which is establishing relationships between this information and the values of the viewer or reader (Zülsdorf-Kersting 2009, p. 14). However, as Bernhardt (2012, p. 16) argues, there is little conceptual clarity about what a Werturteil actually entails, apart from the inclusion of personal evaluations, differentiating them from "objective" or factual ones. This could become especially fuzzy when the subject matter is Nazism and the Holocaust because of its potentially traumatic nature which entwines facts with emotions.

The teaching of the Holocaust is varied and there are no national, unified state objectives or teaching and learning criteria. Each 16 Bundesländer (federal states) and each four existing school forms has its own curriculum that describes suggested contents. Despite this diversity, based on a government document that describes educational expectations of each province with regard to the topic, the following can be noted: in all provinces and in all school types the study of National Socialism and Holocaust is mandatory in history education; there is sometimes focus on "problems reparation Wiedergutmachung [which literally means making right again], and remembrance" (Ministry Culture 2005, p. 38) and inviting Shoah survivors to speak to pupils, and making excursions to "authentic" sites of remembrance are encouraged. For example, in Mecklenburg-Vorpommern pupils in the $9^{\text {th }}$ grade are to "take hold of", "grasp", "realise", or "get sense of" (erfassen) "the inhumanity and the barbarity of the industrially organised genocide on the basis of the Auschwitz concentration camp" (ibid, p. 25) ${ }^{4}$. Such encounters and excursion are designed to turn "memory culture" (Memorialkultur) into means for developing "social and self-competence" (ibid, p. 24).

Most curricula operate on the basis of developing such competencies, whereby in history education those competencies are usually encouraged that are deemed necessary for "dealing with" or "mastery" (Bewältigung) of and finding solutions to "societal challenges on the basis of a reflected understanding of a democratically constituted society" (ibid, p. 11). Other competencies in history education include the ability make reasoned judgements (Urteilskompetenz), media and method competence, and narrative competence (Weinhold \& Komatowsky 2013, p. 5). In addition, various other (related) concepts mark the landscape of history learning. These are: historical consciousness (the temporal orientation across past, present and future), Fremdverstehen (ability to understand "otherness"), self-reflection, and orientation-competence (relevance of a story told by a witness to own life situation) (see Barricelli et al. 2009, p. 14). None of these explicitly state how emotions, affects or feelings of the pupils, or the historical actors, or the interaction between them,

3 All translations from German English are the author's, unless the source used was already on translation.

4 http://www.kmk.org/fileadmin/Dateien/pdf/Bildung/AllgBildung/ZusammenfassungHolocaust-November-05_01.pdf 
or empathy with the victims or the perpetrators, could be made the object of or the vehicle for historical understanding.

While this is also partly true for the Anglo-Saxon context, there is more specification regarding making value judgements, as opposed to purely factual ones that are based more on rational (measurable), objective criteria. For example, in the Canadian curriculum, an ethical dimensions of historical thinking is specified, involving the making of moral judgements (Seixas 2006) which asks about the "responsibilities that historical crimes and sacrifices impose upon us today" $(\mathrm{CSHC})^{5}$. While there is also rationality (factual knowledge) involved in making such judgements, there is at the same time a heavier reliance on personal-emotional factors because value systems that define what is right and wrong tend to be more individual, including biographical influences by drawing on subconscious factors. Rüsen and Straub (1998, p. 9) emphasise that in the German context unconscious factors that determine the mental processes of historical consciousness influence the specific meaning-making achievements that are about the conception and representation of history as an experience of "processing" (Verarbeitung) the past. Once again, it becomes clear that the focus is on "dealing with" or "working through" the burdens of the past and this involves, by implication, emotional factors that are not realisable in a purely objective way. The meaning of those factors that could be connected to the subconscious, like wishes, desires, experiences and sentiments of the viewer or reader is not the object of research and it would be inaccurate to speak of a research agenda that deals explicitly with attitudes and values in German history education (Bernhardt 2012, p. 16).

In the British context, Peter Lee (2011, p. 67) stresses that history education "is a matter not of indoctrinating students but of helping them understand that asking a serious question about the past implies subscribing to certain values", which involves an ethical decision. Such a decision is based on certain notions of absolutes (as opposed to relatives) that permits the condemnation of gross injustices. It requires "that we entertain the notion of an historically transcendent human commonality", which is the recognition of "our humanity in the person of historical actors" (Seixas and Peck 2004, p. 113). Such moral judgements require empathetic understanding, which includes understanding both the similarities and the differences between the moral universes of the historical actors and those who read about them (ibid.). As such, although empathy is considered to be part of historical thinking in Canada, it is still not clear how exactly it is related to memory and emotions.

This is also true in Germany: given the differences across the federal staks, there is not one specified state position on how memory, remembering and emotions fit into the learning of history and thus they remain undefined. Nevertheless,

5 Centre for the Study of Historical Consciousness, http://historicalthinking.ca/ethical-dimensions, last accessed 30 January 2018. 
a focus on memory (rather than on empathy) is generally included, which might have to do with the consideration that memory (as in remembering someone or something, not memory as a theoretical concept) is more easily mediated or measured in educational context than empathy. "The memory of the Holocaust victims must be kept alive" is part of the mandate in history curricula (Meseth \& Proske 2010, p. 202), even though, as the above examples show, the available references do not make it clear how exactly this is to be transformed to learning, apart from aiming at some type of general self-reflection and the attainment of various abstract competencies. The gaps are filled in by writings of specialised Geschichtsdidaktiker ${ }^{6}$ working at academic institutions and by prominent voices from educational and political organisations. The result is that it is mostly up to teachers to translate their local curricular ideas and ideals into educational units that they - in their professional capacity ${ }^{7}$ - deem meaningful and relevant. Teachers in Germany have considerable autonomy in this regard and pupils' learning success is said to depend on the teachers' skill and craft (Geschick) (Ministry of Culture 2005, p. 28), which in turn is related to the type of teacher education they have received. In addition to formal lessons, teachers are also encouraged to teach this topic through projects, work groups and history workshops. In sum, much weight is given to Holocaust education in secondary schools, but the curricula are diverse and they keep the learning objectives and teaching methods abstractly vague. This could be interpreted as both a constraint and an opportunity for teachers (and thus for pupils), depending on their personal interests, creativity, initiative-taking, level of engagement and moral-political convictions.

\section{Emotions, feelings, affects and their role in German Geschichtsdidaktik}

Although the scientific literature distinguishes between affects, feelings and emotions, for the purpose of this article it suffices to talk about them in a generic, collective way. The aim here is not to discuss their differences but rather to agree with those scholars who critically view the overvalued role assigned to reason and rationality in politics, ethics, and aesthetics (Leys 2011, p. 435), adding history education to the list. By "emotions" I will thus be referring to all three: affects, which is a non-conscious experience of intensity; feelings, which are sensations measured against previous biographical experience (and are thus related to memory); and emotions, which are projections or displays of feelings (Shouse, 2005, p. 1). Therefore it is emotions that make it possible to communicate about affects and

6 Academics specialising in the study of teaching and learning the subject history in schools.

7 Teachers in Germany qualify by completing a masters degree of about five years. In addition, they have to absolve a practical training period (in Nordrhein Westfalen it is 18 months) in schools usually not of their choosing, assessed by subject advisors. Once they qualify, they become life-long public servants with special responsibilities and privileges. 
feelings because emotions are always filtered or mediated by means of language (Meyer-Hamme 2013, p. 128). Given their embeddedness in language, emotions are therefore inextricably linked to historical understanding because of the connection between emotion and cognition which is realised mentally by way of narrating a story (Rüsen 2013a, p. 34). The resulting historical consciousness is characterised by a complex interplay between the subjectivity (inner world) and objectivity (outer world) of experience (Rüsen 2013b, p. 284). Meaning-making is always coupled to sensory references and does not occur automatically as a result of cultural processing of empirical facts or statements of facts (ibid). Therefore emotions are seen as an inevitable part of meaning-making.

Despite of these attempts to overcome the emotion-cognition dichotomy, history tends to be regarded as a discipline that is sceptical about the involvement of emotions in mediating historical content because it is considered to "interfere" (i.e. cancel out or be detrimental to) the ability to take up such contents cognitively (rationally) (see Schönert and Weckwerth 2011). The phrase "crying does not educate" is used to sum up this point of view (ibid., p. 298). Von Borries (2014, p. 12-13) wonders why a "purely intellectual and cognitive understanding" has come to characterise the handling of history, given that in some of the "grand" historians' writings (talking about Meinecke's and Ranke's) a focus on aesthetics and emotionality is clearly recognisable. One answer could be that in the 1960 s and 1970 s there was a shift in the approach to learning history at schools. Schörken (1994, p. 114-15) explains that until then history education was based purely on narratives that built the historical imagination of pupils. Then there was a shift as a result of the popularity of cognitive learning theories espoused by Benjamin Bloom (and his famous taxonomy) that enabled a systematic grading of cognitive and emotional learning performances. This (supposedly) allowed for a better understanding of learning processes and thus for their better planning and controllability. However, what this process also did was to hierarchise "concrete" and "abstract", whereby abstract was thought to replace the concrete in the more able student. As such, the concrete, which is associated with physicality and thus with affections and emotions (see Brauer 2016, p. 34), was regarded as somewhat inferior to cognitive mental abilities, even though, as Schörken asserts, the concrete does not substitute the abstract in historical understanding. Rather, the two should be understood as mutually dependent (p. 115).

Even the "father of human sciences" philosopher Wilhelm Dilthey regarded emotions as a central element in the scientific method because for him "real life processes" were key for perceiving the world through the will, feelings and imagination (Morat 2008, p. 105). For Dilthey, these three elements were to be seen as co-existent and equally fundamental for making sense of the world. As such, these "inner experiences" of humans are given to them a priori and since that which happens on the outside always appears to a person, that which is going on inside cannot be interpreted as directly resulting from environmental processes. On this 
view, "imagination" belongs to the same category as "emotions" by its association with feelings and affects. Ricoeur (2004, p. 5) for example said that imagination is located "at the lowest rung of the ladder or modes of knowledge, belonging to the affections that are subject to the connection governing things external to the human body", and together with cognition are the "load bearing pillars for the reconstruction (Nachvollzug) of the past in the present" (Schörken 1994, p. 12). Despite Ricoeur's emphasis of both cognition and emotion, a hierarchisation is still evident in his writing that elevates cognition above emotion (or imagination). This results from a dualistic worldview that lives off separating the "order of the affections and the body" from "the order of ideas and the intellect" (Ricouer 2004, p. 5).

This dualistic view has also influenced Geschichtsdidaktik, even though it is not disputed that emotions shape consciousness, perceptions and memory, and are thus a central category of historical learning and of historical meaningmaking (Brauer \& Lücke 2013, p. 19). Despite this, historically there has been a fear that emotions have incalculable effects due to their fluidity and indeterminacy, which are thought to affect historical learning in negative ways, with possible manipulative-indoctrinating intentions and consequences (ibid., p. 15). Added to this is the Überwältigungsverbot (prohibition against being "overwhelmed") of the Beutelsbacher Konsens of 1976, which originally, in a political-educational context, was concerned with indoctrination and measures that would lead to preventing pupils from forming their own opinions. However, this has since been applied to history education and transferred in meaning to refer to a prohibition against emotionally overwhelming pupils (see Brauer 2016, p. 40-41), even though by this author's own argument emotions are culturally and temporally specific (ibid., p. 29), which would make it difficult to measure and determine what is "overwhelming" for a particular person belonging to a particular cultural group.

In the German context, this is again related to the legacy of the past when it comes to representations of the Holocaust. There are different standards compared to the Anglo-American and other European contexts (see ibid., p. 39). In Germany the representation of the Holocaust tends to be treated with "restraint" and with "wary or cautious interventions" (behutsame Eingriffe) (Schönert and Weckwerth 2011, p. 289). For example these authors note, referring to a traveling exhibition about the euthanasia programme of the Nazis by the United States Holocaust Memorial Museum in Washington DC, hosted in Dresden between 2006 and 2007, that museum specialists in Germany would not have had the courage to use the same (high) degree of emotional appeal as their American colleagues did for this monstrous subject (ibid., p. 287) ${ }^{8}$. Perhaps this is why, according

8 See "Deadly Medicine, Creating the Master Race", USHMM: Washington DC, 2004. https:// www.ushmm.org/information/exhibitions/traveling-exhibitions/deadly-medicine, and http:// www.tagesspiegel.de/kultur/ns-euthanasie-ausstellung-toedliche-medizin-in-dresden/76219o. html, both last accessed 26 February 2018. 
to Geschichtsdidaktikerin Bärbel Völkel (2013, p. 159), the status of historical consciousness in Germany is still rather positivist and does not actively seek to understand the interaction between knowledge, intelligence, and emotional implications. It is against this background that an educational medium is described that uses virtual testimony by Shoah witnesses in history education. This medium can be understood as an opportunity to ease this strict divide between the emotional and the rational by way of creating a platform of exchange between a testifier and a listener. This medium will be described next and it will be explained how the act of giving testimony can be understood theoretically.

\section{The educational medium: virtual testimony and the tertiary witness}

The DVD series "Witnesses of Shoah-school learning with video-interviews"9 was conceptualised in the light of the fact that real witnesses are becoming fewer and fewer and that somehow their memory needed to be preserved and made accessible in another way for educational purposes. The DVD series consist of 12 video-interviews on four DVDs that were first recorded between 1994 and 1999 as part of the Steven Spielberg Visual History Archive (VHA) that contains more that 52000 of them. Between 2008 and 2011 academics from the Freie Universität in Berlin developed an extensive learning software package as part of the series based on the interviews. Each of the four DVDs is based on a theme, namely "fleeing", "surviving", "resisting" and "carrying on living" respectively. There are two levels on each DVD. One is called "history" and the other "remembrance". On the "remembrance" level the personal accounts of the (mostly victim) witnesses are reproduced in edited form (shortened from about two hours to about 30 minutes each). On the "history" level a wide array of complementary, multimedial materials (primary and secondary sources in all imaginable formats) are provided for the solving of the intellectually demanding tasks that are part of the learning software. These materials add to the perspectives of the victims and also to resistors but exclude perpetrator perspectives.

The unique quality of this medium is the virtual space in which the witnessing takes place. Bothe \& Sperling (2013, p. 209-210) claim that in this virtual space of experience, the testimonies of the survivors are received in an especially intensive manner, whereby the performative act of the witnesses are transferred into the virtual space, leading to a negotiation of meaning ("secondary dialogue") regarding the remembrance of the Shoah. To the recipient it seems as if there was a direct encounter between him or her and the witness, which is made possible by the visibility of the spoken word and the body language, promoting an empathetic watching and listening (Nägel 2016, p. 250). But unlike real-life encounters, there is no possibility of a dialogue, even though, as noted, some refer to the virtual

9 http://www.zeugendershoah.de, last accessed 26 February 2018. 
encounter between witness and recipient as a "secondary dialogue". It is in fact a tertiary witnessing, whereby the pupil/teacher is the witness of the one who bears witness to an interviewer about an event. This tertiary witness can reflect, imagine and surmise, and will probably be left with many questions, making a negotiation of meaning difficult in the absence of the required information. Nevertheless, the function of bearing witness remains.

This function can be described as follows: when pupils watch and listen to these testimonies, they are encountering a traumatic (emotionally loaded) memory. Thus it is not just a matter of listening to an abundance of dramatic experience or absorbing the facts, but about the "experience of my inexperience to hear and learn" (Simon 2000, p. 19). This requires "attending to the specific procedures for defining, legitimating, and validating information [...] and judgements about what is regarded as factual evidence and about how such evidence should be interpreted" (Simon and Eppert 1997, p. 179). As such, bearing witness includes the emotional and the factual in a very integrated sense. The interpretations as thus described may not fit in with traditional historiography because they go beyond the factual, the measurable and the chronological recording of time, place and events: "to witness testimony is to be claimed to another in ways that are not reducible to blood ties, geographically local or diaspora identities, or humanistic assertions of empathy. This is because in a witnessing relation, one must become open to the possibility of unforeseen memory, the possibility of unfamiliar, unexpected connections that disrupt attempts to know what meaning a place or moment may hold" (Simon 2000, p. 18-19).

Within such a conceptualisation, remembering means recognising how something came to be (Greve 2014, p. 17) and is thus a reminder to not take life for granted and also to hold onto a hope for a better future.

When it comes to the traumatic moments in the testimony, Dori Laub (in Simon \& Eppert 1997, p. 182) refers to excesses, which are often an inherent structural feature of such testimony. They infiltrate moments of the testimony in which the witness feels accountable towards those who no longer can bear witness, indicating that it is about justice. It "allows for truths to emerge from a plane on which testimonial reference cannot be recognised and adjudicated as discursively organised knowledge" (ibid., p. 182) but can be appropriated (made sense of) emotionally with the heart. This presents a considerable challenge for the teaching of history, which can hardly accommodate non-discursively organised knowledge in its pursuit of truth (verifiable facts) by means of what is considered historical evidence. Nevertheless, the idea is that by listening to and watching the virtual testimonies, new historical thinking competencies are developed among pupils that may not be identifiable in conventional, traditional ways. 


\section{Conclusion}

In the German context using Holocaust testimonies in history education poses special challenges and opportunities. It is not just about integrating emotional content into a curriculum that is largely based on factual, rational understanding of the past. "Emotional" is often equated with "emotionalising" in the sense of invoking or placing a sense of responsibility on pupils for the consequences of the deeds committed by the forefathers; deeds that were sanctioned from "home soil". In this essay I have shown how the historical development and theoretical underpinnings of the history curriculum are such that they tend to keep specific emotional and ethical involvements of pupils in history learning abstract, possibly so as to avoid having to address in prescriptive ways how to deal with the mentioned legacy in concrete terms.

However, historically this abstraction process is relatively new because up until the 1960 or or 1970 s history education was based purely on narratives that built the historical imagination of pupils, including the related ethical and emotional dimensions that have become neglected as a result of the heavier focus on factual and objective (measurable) learning criteria. The development of a relatively new educational medium, namely that of virtual testimonies on DVDs complete with learning tasks and supplementary materials relevant for history learning, steps into this gap by allowing pupils to become tertiary witnesses to traumatic narratives of Holocaust survival. Such witnessing is not just about learning particular lessons (moral or otherwise) from the memories of those who lived through this trauma. It is also about understanding what transpires during the excess moments of a traumatic memory in which discursively organised knowledge might not be adequate. An empirical case study of how this can materialise in a classroom setting and what its relevance is will be the topic of a future essay.

\section{References}

Barricelli, Michele; Brauer, Juliane and Wein, Dorothee. 2009. "Zeugen der Shoah: Historisches Lernen mit lebensgeschichtlichen Videointerviews. Das Visual History Archive des Shoah Foundation Institute in der schulischen Bildung". Medaon, Volume 5.

Bernhardt, Markus. 2012. "Einstellungen Jugendlicher gegenüber Geschichte und Geschichtsunterricht", in Zeitschrift für Geschichtswissenschaft 3(1): 14-30.

Bothe, Alina and Sperling, Rolf. 2012 "Trauma und Emotionen im virtuellen Raum. Historisches Lernen über die Shoah mit virtuellen Zeugnissen" in Juliane Brauer und Martin Lücke(Eds.) Emotionen, Geschichte und historisches Lernen. Geschichtsdidaktische und geschichtskulturelle Perspektiven. Göttingen: V\&R Unipress, pp, 201-221.

Brauer, Juliane and Lücke, Martin (Eds.) 2013. Emotionen, Geschichte und historisches Lernen. Geschichtsdidaktische und geschichtskulturelle Perspektiven. Göttingen: V\&R Unipress. 
Brauer, Juliane. 2016. "'Heiße Geschichte? Emotionen und historisches Lernen in Museen und Gedenkstätten”, in Sarah Willner, Georg Koch, Stefanie Samida (Eds.), Doing History. Performative Praktiken in der Geschichtskultur, Münster: Waxmann, pp. 29-44.

Brauer, Juliane and Wein, Dorothee. 2009. "Zeugen der Shoah: Historisches Lernen mit lebensgeschichtlichen Videointerviews. Das Visual History Archive des Shoah Foundation Institute in der schulischen Bildung", in Medaon, pp. 1-17.

Crossland, David. 2012. "The Holocaust Is German Family History. Book Urges Germans to Quiz Dying Nazi Generation”, Spiegel Online, http://www.spiegel.de/international/ germany/feature-on-historical-research-into-a-german-family-s-nazi-history-a-826633. html, last accessed 23 February 2018.

Greve, Astrid. 2014. Zachor - Erinnern lernen. Aktuelle Entdeckungen in der jüdischen Kultur des Erinnerns. Berlin: epubli GmbH.

Körber, Andreas. 2011. "German History Didactics : From Historic al Consciousness to Historical Competencies - and Beyond ?", in Bjerg, Helle, Lenz, Claudia, Thorstensen, Erik (Eds.) Historicizing the Uses of the Past. Scandinavian Perspectives on History Culture, Historical Consciousness and Didactics of History Related to World War II. Bielefeld: transcript Verlag, 145-164.

Kühner, Angela. 2008. "NS-Erinnerung und Migrationsgesellschaft: Befürchtungen, Erfahrungen und Zuschreibungen" in Einsichten und Perspektiven, 52-65.

Lee, Peter. 2011. "History education and historical literacy". In Ian Davies (Ed.) Debates in History Teaching, London: Routledge, 63-72.

Leys, Ruth. 2011. "The Turn to Affect: A Critique”, in Critical Inquiry 27 (3): 434-472.

Lücke, Martin. 2009. "Überlebensgeschichten. Sprache und historisches Lernen zum Thema Holocaust mit Video-Interviews aus dem Visual History Archive", in Medaon 5: 1-5.

Meseth, Wolfgang and Matthias Proske. 2010. "Mind the Gap: Holocaust education in Germany, between pedagogical intentions and classroom interactions," Prospects 40, 201-222.

Meyer-Hamme, Johannes. 2013. “'I never liked history at school.' Identitäten und Emotionen beim historischen Lernen", in Juliane Brauer \& Martin Lücke (Eds.) Emotionen, Geschichte und historisches Lernen. Geschichtsdidaktische und geschichtskulturelle Perspektiven. Göttingen: V\&R Unipress, 125-137.

Ministry of Culture, 2005. "Unterricht über Nationalsozialismus und Holocaust", http:// www.kmk.org/fileadmin/Dateien/pdf/Bildung/AllgBildung/ZusammenfassungHolocaust-November-05_01.pdf, last accessed 23 February 2018.

Morat, Daniel. 2008. "Verstehen als Gefühlsmethode. Zu Wilhelm Diltheys hermeneutischer Grundlegung der Geisteswissenschaften", in Daniel Morat and Uffa Jensen (eds.) Rationalisierungen des Gefühls. Zum Verhältnis von Wissenschaft und Emotionen 1880-1930, München: Wilhelm Fink Verlag, pp. 101-117.

Nägel, Verena Lucia. 2016. "Zeugnis - Artefakt - Digitalis. Zur Bedeutung der Enstehungsund Aufbereitungsprozesse von Oral Histroy-Interviews", in Sonja Knopp; Sebastian Schulze and Anne Eusterschulte (Eds.) Videographierte Zeugenschaft. Ein interdisziplinärer Dialog. Weilerwist: Velbrück Wissenschaft, pp. 347-368. 
Ricoeur, Paul. 2004. Memory, History, Forgetting, translated by Kathleen Blamey and David Pellauer, Chicago: University of Chicago Press.

Rüsen, Jörn. 2013a. "Die Macht der Gefühle im Sinn der Geschichte. Theoretiche Grundlagen und das Beispiel des Trauers" in Juliane Brauer and Martin Lücke (Eds.) Emotionen, Geschichte und historisches Lernen. Geschichtsdidaktische und geschichtskulturelle Perspektiven. Göttingen: V\&R Unipress. pp. 27-44.

Rüsen, Jörn. 2013b. Historik: Theorie der Geschichtswissenschaft, Köln: Böhlau.

Rüsen, Jörn and Straub, Jürgen (Eds.) 1998. Die Dunkle Spur der Vergangenheit. Psychoanalytische Zugänge zum Geschichtsbewusstsein Erinnerung, Geschichte, Identität, 2nd ed.; Suhrkamp Verlag: Berlin, Germany, pp. 9-10.

Schönert, Volker and Weckwerth, Susanne. 2011. "Emotionale Überwältigung?" in Bert Pampel (Ed.) Erschrecken - Mitgefühl - Distanz. Empirische Befunde über Schülerinnen und Schüler in Gedenkstätten und zeitgeschichtlichen Ausstellungen. Leipzig: Leipziger Universitätsverlag, pp. 283-305.

Schörken, Rolf. 1994. Historische Imagination und Geschichtsdidaktik. Paderborn: Ferdinand Schöningh.

Seixas, Peter and Peck, Carla. 2004. "Teaching Historical thinking”, in Sears A., and Wright, I. (eds.), Challenges and Prospects for Canadian Social Studies, Vancouver: Pacific Educational Press, pp. 109-117

Seixas, Peter. 2006. Benchmarks of historical thinking: A framework for assessment in Canada.University of British Columbia: Centre for the Study of Historical Consciousness, http://historicalthinking.ca/sites/default/files/files/docs/Framework_EN.pdf, last accessed 23 February 2018.

Shouse, Eric. 2005. "Feeling, Emotion, Affect” Media Culture Journal, 8(6). http://journal. media-culture.org.au/o512/03-shouse.php, last accessed 30 January 2018.

Simon, Roger I. and Claudia Eppert. 1997. "Remembering Obligation: Pedagogy and the Witnessing of Testimony of Historical Trauma". In Canadian Society for the Study of Education, Vol. 22 (2): 175-191.

Simon, Roger I. 2000. “The Paradoxical Practice of Zakhor: Memories of 'What Has Never Been My Fault or My Deed '”. In Roger I. Simon, Sharon Rosenberg, and Claudia Eppert (Eds.) Between Hope and Despair: Pedagogy and the Remembrance of Historical Trauma. Lanham, Maryland: Rowman \& Littlefield, pp 9-25.

Völkel, Bärbel. 2013. "Verstörende Imaginationen. Gedanken zum Zusammenhang von historischen Imaginationen und Emotionen" in Juliane Brauer \& Martin Lücke (Eds.) Emotionen, Geschichte und historisches Lernen. Geschichtsdidaktische und geschichtskulturelle Perspektiven. Göttingen: V\&R Unipress, pp. 139-164.

Von Borries, Bodo. 2014. Zwischen 'Genuss' und 'Ekel' - Ästhetik und Emotionalität als konstitutive Momente historischen Lernens (mit Beiträgen von Johannes Meyer-Hamme), Schwalbach am Taunus: Wochenschau Verlag.

Weinhold, Andreas \& Komatowsky, Meike. 2013. "Holocaustpädagogik in der Zeitzeugenkultur. Für eine reflektierte Nutzung von Zeitzeugeninterviews in historisch-politischen Lernprozessen zum Holocaust". Die Internationale Schule für Holocaust-Studien, 
http://www.yadvashem.org/yv/de/education/newsletter/o8/article_weinhold.asp, last accessed 23 February 2018.

Zülsdorf-Kersting, Meik. 2009. „Weil das eben die Befehle sind'. Jugendliche erklären das Täterhandeln im Holocaust. Empirische Befunde”, in Medaon 5 (3). http://www. medaon.de/de/artikel/weil-das-ebend-die-befehle-sind-jugendliche-erklaeren-das-taeterhandeln-im-holocaust-empirische-befunde/

\section{W JAKI SPOSÓB TRAUMATYCZNE RELACJE ŚWIADKÓW HOLOKAUSTU SĄ WŁĄCZANE W NAUCZANIE HISTORII NIEMIEC?}

Streszczenie: W niniejszym eseju prześledzone są sposoby, w jakie traumatyczne relacje świadków Holokaustu zostały włączone w program nauczania historii Niemiec. Szczególną uwagę zwraca się na to, w jaki sposób uczniowie powinni zrozumieć kwestie Narodowego Socjalizmu i Holokaustu. Programy nauczania są zróżnicowane, a ich cele i metody związane z emocjami, wyobraźnią i wymiarem etycznym nie są - zgodnie z charakterem tego zagadnienia - wyraźnie zdefiniowane. Sytuacja ta stawia nauczycieli i uczniów przed pewnymi wyzwaniami, ale też możliwościami. Jedną z takich możliwości jest wykorzystanie wirtualnych przedstawień relacji świadków Holokaustu. Emocjonalne, opisujące traumatyczne wspomnienia narracje pozwalają uczniom przyjąć funkcję postronnych świadków; proces ten został pokrótce opisany. Trudności wynikające z wykorzystania ustnych przekazów polegają na tym, że są niedyskursywnym źródłem wiedzy, a nie dowodami historycznymi w tradycyjnym ich rozumieniu.

Słowa kluczowe: Holokaust, edukacja, emocje, trauma, historia, program nauczania, kompetencje, dualizm.

Katalin Eszter Morgan studied Sociology and Education in Johannesburg (South Africa), focusing on Social Science, History and Technology. Her PhD thesis completed in 2011 examined the representation of Nazism and the Holocaust in South African high school history textbooks. The publications from this work centered around issues of race, racism, stereotypes, as well as on theoretical issues pertaining to textbook analysis more generally. In 2015 she relocated to Germany, her former childhood home, to pursue an Alexander von Humboldt-funded post-doctoral study on the use of digitised, video-graphed Shoah victim testimonies. She is currently working on several papers documenting the results of this study, based at the University Duisburg-Essen. She is also working on a book project that draws on her personal biography to illuminate her experiences in the field. Her other research interests include Antisemitism, inherited or generational guilt and trauma, learning technology and media design, philosophy of history, and theories of memory. E-mail-Address: katalin.morgan@uni-due.de. 